\title{
Salmonella Heidelberg resistant to ceftiofur and disinfectants routinely used in poultry
}

\section{Salmonella Heidelberg resistente ao ceftiofur e desinfetantes rotineiramente utilizados na avicultura}

\author{
Lenita Moura Stefani ${ }^{*}$; Gabriella Bassi das Neves ${ }^{2}$; Maiara Cristiane Brisola ${ }^{3}$; \\ Regiane Boaretto Crecencio ${ }^{3}$; Eduarda Caroline Pick ${ }^{3}$; Denise Nunes Araujo ${ }^{3}$
}

\begin{abstract}
Bacteria of the genus Salmonella may infect humans and domestic animals, causing a serious public health problem worldwide. Nowadays, Salmonella enterica serovar Heidelberg (SH) is among the top three serovars isolated from people with salmonellosis and it is present in the poultry production chain. Moreover, it seems to be more invasive than other serotypes that cause enteritis. The overall status of the antimicrobial resistant of Brazilian strains of SH is still unknow. The bacterium may use similar mechanisms of resistance to antibotics, as well as disinfectants such as the efflux system and enzymatic degradation of chemical compounds. Thus, the objective of this study was to identify the Minimal Inhibitory Concentration (MIC) for ceftiofur of SH isolated from different materials of poultry origin, as well as to verify the relation between antibiotic resistance and disinfectant resistance. In addition, the screening efflux system was performed, using ethidium bromide to determine the presence of this mechanism of resistance. MIC results indicated high levels of SH resistance to ceftiofur, indicating the need for alternative drugs to treat salmonellosis. The concentration of ceftiofur needed to eliminate $\mathrm{SH}$ resistant isolates were 32 times higher than the therapeutic dose. Regarding disinfectants, most of the disinfectants tested were efficient to eliminate SH, however one isolate was resistant to glutaraldehydequaternary ammonia. All isolates were negatives in the screening efflux system, which suggest a different mechanism of resistance. It is possible to conclude that SH shows a real threat to poultry production, and caution should be taken when choosing the right antibiotic and disinfectant against this serovar. Key words: Ceftiofur. Disinfectant. Public health. Resistance. S. Heidelberg.
\end{abstract}

\section{Resumo}

Bactérias do gênero Salmonella podem infectar o homem e animais domésticos, causando sérios problemas de saúde pública no mundo todo. Hoje, a Salmonella enterica serovar Heidelberg (SH) está entre os três sorovares mais comumente isolados de pessoas com salmonelose, e presente na cadeia produtiva avícola. Além disso, SH parece ser mais invasiva que outros sorovares que causam enterite. O perfil geral de resistência aos antimicrobianos de cepas brasileiras de SH ainda é desconhecido. Esta bactéria parece usar mecanismos de resistência aos antibióticos similares aos usados para desinfetantes, tais como a bomba de efluxo e a degradação enzimática de compostos químicos. Por isso, o objetivo

1 Prof A Associada, Programa de Pós-graduação em Zootecnia, Universidade do Estado de Santa Catarina, UDESC, Chapecó, SC, Brasil. E-mail: borrucia@hotmail.com

2 Discente de Doutorado, Programa de Pós-graduação Multicêntrico em Bioquímica e Biologia Molecular, UDESC, Lages, SC, Brasil. E-mail: gabi_zootec@yahoo.com.br

3 Discentes de Mestrado, UDESC, Chapecó, SC, Brasil. E-mail: regibc@gmail.com; maiarabrisola@yahoo.com.br; eduarda. pick@bol.com.br; dnaraujo@hotmail.com

* Author for correspondence 
deste trabalho foi de identificar a Concentração Mínima Inibitória (CMI) para o ceftiofur de isolados de SH oriundas de produtos avícolas diversos, bem como de verificar a relação entre resistência a antibióticos e desinfetantes. Além disso, o sistema de bomba de efluxo foi realizado usando o brometo de etídio para determinar se esse era o mecanismo de resistência utilizado. Os resultados do MIC indicaram altos níveis de resistência para ceftiofur, demonstrando a necessidade de formas alternativas para o tratamento da salmonelose. Desinfetantes routineiramente utilizados pela indústria avícola foram eficientes no combate da SH, porém um isolado mostrou-se resistente ao desinfetante glutaraldeído associado à amônia quaternária. Todos os isolados foram negativos para o sistema de bomba de efluxo, sugerindo que há outro mecanismo de resistência envolvido. É possível concluir que os isolados brasileiros de SH representam uma ameaça para a avicultura, e cautela deveria ser tomada na hora da escolha do antibiótico e do desinfetante a ser utilizado contra este sorovar.

Palavras-chave: Ceftiofur. Desinfetante. Resistência. Saúde pública. S. Heidelberg.

\section{Introduction}

Poultry production currently stands out in the Brazilian agribusiness by generating millions of jobs in the country and raising billions of dollars from the exportation. There is an increasing consumption of poultry meat worldwide, which requires continue supply of poultry produts of good quality, where Brazil is the largest chicken meat exporter, and this production is concentrated mainly in three states in the South: Paraná, Santa Catarina, and Rio Grande do Sul. As for the world production of poultry meat, the largest producer is the USA, followed by Brazil (ABPA, 2015).

Salmonella has worldwide distribution being found on a variety of environments, but mainly those of animal production. The ingestion of contaminated food is the main form of human contamination, especially by undercooked or raw eggs. Therefore, Salmonella constitutes a serious public health problem in many countries (BARROW et al., 2010; QUINN et al., 2005). The gastrointestinal illness caused by this bacteria is called salmonellosis (BERCHIERI AND OLIVEIRA, 2006; TERZOLO, 2010).

$S$. Heidelberg (SH) is among the top three serovars isolated from people infected with salmonellosis in Canada. Moreover, it seems to be more invasive than other serotypes that cause enteritis. In Canada, the Canadian Integrated Program for Antimicrobial Resistance Surveillance reported a strong correlation $(r=0.9)$ between $\mathrm{SH}$ isolates resistant to ceftiofur from chicken scraps and the incidence of $\mathrm{SH}$ infections resistant to ceftiofur in humans (DUTIL, 2010). For the treatment of Salmonellosis in farm animals, ceftiofur, a third-generation cephalosporin, is currently the only approved drug (WEBSTER, 2005). In addition to antibiotic treatment, it is also important to use cleaning and disinfecting measures in order to destroy pathogenic microrganisms, including Salmonella. According to Grezzi (2007), quaternary ammonium compounds, glutaraldehyde, and hypochlorite are the main available and active chemical compounds used in poultry.

The abuse and indiscriminate use of antibiotics and even residual concentrations of disinfectants used routinely may lead to the survival of resistant microorganisms (DUTIL, 2010). Some mechanisms, such as the efflux system and enzymatic degradation of the chemical compound are responsible for the resistance to antibiotics and disinfectants, increasing the possibility of cross-resistance (RUSSEL, 2012). There are only a few reports available on the resistance profile specifically for SH regarding ceftiofur (NEVES et al., 2016), and none about disinfectants routinely used in the poultry industry for Brazilian strains of SH. Thus, the objective of this study was to identify the Minimal Inhibitory Concentration (MIC) for ceftiofur of $\mathrm{SH}$ isolated from poultry in the state of Paraná, as well as to verify the relation between resistance to ceftiofur to three of the most common disinfectants used in poultry. In addition, the screening efflux system was performed, using ethidium bromide to detect if this mechanism of resistance was involved. 


\section{Materials and Methods}

\section{Samples}

Salmonella enterica serovar Heidelberg $(n=17)$ of poultry origin were kindly provided by Mercolab Laboratories after serotyping using specific antibodies against $\mathrm{O}$ and $\mathrm{H}$ antigens acoording to Kauffmann-White method (TRABULSI; ALTERTHUM, 2008). They were isolated from Paraná State during 2012 to 2014. Sample source can be seen on Table 2.

\section{Minimum inhibitory concentration (MIC)}

The determination of the Minimal Inhibitory Concentration (MIC) was performed following the recommendations of CLSI (2008). According to the legislation, the isolates were classified as resistant to ceftiofur when the critical point was $\geq 8 \mu \mathrm{g} / \mathrm{mL}$ and sensitive for concentrations $\leq$ than $2 \mu \mathrm{g} / \mathrm{mL}$. MIC was performed using a commercial product (EXCENEL ${ }^{\circledR}$ ) containing $50 \mathrm{mg}$ of ceftiofur per $\mathrm{mL}$ of the product. Ten dilutions ranging from 0.064 $\mathrm{mg} / \mathrm{mL}$ to $0.000125 \mathrm{mg} / \mathrm{mL}$ were used.

\section{Testing disinfectants}

The same 17 strains of SH underwent the dilution method into tubes to determine $\mathrm{SH}$ resistance to disinfectants. Staphylococcus aureus (ATCC 25923) and Escherichia coli (ATCC 25922) were used as controls. Data regarding the disinfectants are described in Table 1. The methodology used to analyze the effectiveness of disinfectants was adapted from the Ordinance number 101 of 11 August 1993 of MAPA using bacterial total count plate (BRASIL, 1993).

The culture medium used for the cultivation of microorganisms was brilliant green agar for $\mathrm{SH}$, nutrient agar for $S$. aureus, and eosin methylene blue (EMB) for E. coli. Gram staining was performed to confirm the presence of $S$. aureus (ISENBERG, 1998). To obtain the suspension of microorganisms, the colonies were subjected to serial dilutions of $10^{1}$ to $10^{7}$, using peptonated water, obtaining a final count of $10^{10} \mathrm{CFU} / \mathrm{mL}$ for each microorganism. The disinfectants (A, B and C) were diluted according to the manufacturer's instructions using sterile distiled water as described in Table 1. The samples were tested in the presence and absence of organic matter (milk) diluted (1:5000) in sterile distilled water.

Table 1. Characteristics of the disinfectants.

\begin{tabular}{lcccc}
\hline Product & Active compounds & Manufacturing date & Expiration date & Dilution \\
\hline Disinfectant A & $\begin{array}{c}\text { benzalkonium chloride 100\% (QAC } \\
\text { and polyethylene glycol ether }\end{array}$ & Apr/14 & Apr/17 & $1: 3000$ \\
\hline Disinfectant B & $\begin{array}{c}\text { benzalkonium chloride (QAC) and } \\
\text { gluteraldehyde 100\% }\end{array}$ & Jun/14 & Jun/16 & $1: 1500$ \\
\hline Disinfectant C & sodium hypochlorite 2\% & Jun/14 & Dec/14 & $1: 100$ \\
\hline
\end{tabular}

For the assay, $9 \mathrm{~mL}$ of each sample of the disinfectant was placed into a tube with $0.1 \mathrm{~mL}$ of the SH suspension. After contact between the inoculum and the disinfectant, the mixture was incubated for 10 minutes at room temperature. The same procedure was repetead for the controls and in the presence of organic matter $(1 \mathrm{~mL})$ (BRASIL, 1993). Each dilution was plated on PCA (plate count agar) and incubated at $37^{\circ} \mathrm{C}$ for 24 hours to verify bacterial counts. 
Screening procedure of the efflux system

Bacterium might be resistant using a pump to exclude chemicals from its inside by a system called efflux system. To evaluate wheather the resistance to quaternary ammonium compounds was mediated by the efflux system, the technique described by Sundheim et al. (1992) was used. Briefly, $0.1 \mathrm{~mL}$ of Brain Heart Infusion broth (BHI) containing SH isolates resistant to ceftiofur as verified by the MIC test, were individually seeded on Mueller-Hinton agar containing ethidium bromide $(0.5 \mathrm{mg} / \mathrm{mL})$ with the aid of a Drigalsky handle. The plates were incubated for $24 \mathrm{~h}$ at $37^{\circ} \mathrm{C}$. After incubation, plates were examined under UV light. Bacterial cells that had accumulated the ethidium bromide would emit a red fluorescence and were considered sensitive to QAC by the absence of efflux pump system.

\section{Results and Discussion}

MIC results for the 17 isolates of $\mathrm{SH}$ to ceftiofur showed result up to $64 \mu \mathrm{g} / \mathrm{mL}$, where only two samples were sensitive to the antibiotic. The respective values of MIC for each $\mathrm{SH}$ isolate are shown in Table 2. Ceftiofur is a third generation cephalosporin of great importance in veterinary medicine, being the only approved cephalosporin for livestock, commonly used to treatment salmonella infections in broilers (WEBSTER, 2005). As can be noted by MIC results, high levels of resistance were identified, indicating that ceftiofur is inefficient on killing this infectious agent, suggesting the need of an alternative drug to treat the infection. To treat salmonellosis in poultry, the concentration of ceftiofur needed is $2 \mathrm{mg} / \mathrm{kg}$. Our results show that the concentration needed to eliminate $\mathrm{SH}$ isolates was 32 fold higher than the therapeutic dose. Frye and Cray (2007) evaluated the susceptibility of isolates of Salmonella spp. from production animals for a period of five years and found that the resistance to ceftiofur increased from $4 \%$ in 1999 to $18 \%$ in 2003. In this same study, MIC values ranged from 1 to $16 \mu \mathrm{g} / \mathrm{mL}$, differently from our findings. Zhao
(2008), also analyzed SH isolates from chicken meat scraps, and found lower levels of resistance (9\%) to ceftiofur. In addition, Medeiros et al. (2011) found higher levels of ceftiofur resistance in isolates of $\mathrm{SH}$ from carcasses and chicken meat, to similar levels as observed in this study. The increased resistance to broad spectrum, third generation cephalosporins in isolates of Salmonella spp is of significant interest to public health, since ceftriaxone is an important drug used to treat children with severe salmonellosis. Considering that ceftiofur resistant microorganisms may cross-resistant to ceftriaxone, the use of this antimicrobial agent in food animals is under increased scrutiny for being a potential agent responsible for the emergence and spread of resistance to ceftriaxone in Salmonella spp. and other enteric pathogens in humans (FOLEY; LYNNE, 2007; DUTIL, 2010).

Of the 17 isolates of $\mathrm{SH}$ that underwent dilution test with disinfectants, 16 were sensitives to all three disinfectants at the recommended dilution, regardless of the presence of organic matter (milk). However, a single isolate of $S$. Heidelberg (ID 81) inoculated in the absence of organic matter grew even in the presence of the disinfectant $\mathrm{B}$ (benzalkonium chloride (QAC) and gluteraldehyde $100 \%)$. The quaternary ammonium compounds (QACs) are synthetic cationic detergents that have antimicrobial activity. This sanitizer is soluble in water, with low toxicity and efficient against Grampositive bacteria and thermoduric microorganisms, but poorly effective against Gram-negative bacteria, coliforms, and spores (WALIA et al., 2017). Disinfectant A (quaternary ammonium) used in this study, has polyethylene glycol ether in its composition. According to Kich et al. (2004), this compound is characterized by the surfactant action, able to remove biofilms. It was concluded that the 17 isolates of SH were killed in vitro in the presence of this disinfectant, both in the presence and absence of organic matter (milk). Glutaraldehyde and quaternary ammonium (disinfectant B) have a synergistic effect, associated with a higher 
success in the control of bacteria, exerting lower selection pressure in microbial populations (FIGUEIROA et al., 2017). Both compounds have been used routinely by the Brazilian poultry industry. Ammonia-based products, and quaternary aldehydes are very effective in eliminating $E$. coli in contaminated environments (GILBERT; MCBAIN, 2003). However, in the present work disinfectant $B$ was not fully efficient to eliminate $\mathrm{SH}$, since one isolate (ID 81) was resistant. According to Gilbert and Mcbain (2003), many Gram negative pathogens might be resistant to disinfectants, since they have a relatively impermeable outer membrane of the cell wall (SUNDHEIM, 1992), which could justify our findings. We observed that the disinfectant C (2\% sodium hypochlorite) was effective in killing $\mathrm{SH}$ isolates either in the presence or absence of organic matter (milk). Overall chlorinated compounds are widely used due to its low cost (BUNCIC; SOFOS, 2012).

Table 2. Identification, source and Minimum Inhibition Concentration (MIC) results using ceftiofur against Brazilian strains of Salmonella Heidelberg.

\begin{tabular}{ccc}
\hline ID strain & Source & MIC $(\mu \mathrm{g} / \mathrm{mL})$ \\
\hline 52 & Meat product & 32 \\
53 & Meat product & 64 \\
54 & Meat product & $>64$ \\
55 & Culture & 2 \\
56 & Culture & 64 \\
57 & Culture & 64 \\
62 & Meat product & 64 \\
69 & Meat product & 64 \\
70 & Meat product & 64 \\
77 & Drag swab & 32 \\
79 & Meat product & 64 \\
80 & Drag swab & 64 \\
81 & Drag swab & 32 \\
82 & Drag swab & 64 \\
91 & Dead birds & 32 \\
103 & Drag swab & $>64$ \\
104 & Drag swab & $<2$ \\
\hline
\end{tabular}

Several authors have reported that bacterial resistance to disinfectants might be related to the presence of the efflux system to pump out toxic substances from inside the bacterial cells (PAIXÃO et al., 2009). Our findings support this hypothesis, since the strains were sensitive to disinfectants and efflux mechanism was not observed in any of the isolates. The same was observed by Bjorland et al. (2005) while analyzing isolates of Staphylococcus spp. from milk of cattle and goats that were resistants to quaternary ammonium compounds. Therefore, we conclude that a different mechanism might be related to this type of resistance, and further tests should be performed such as sequencing to verify gene mutations in genes associated with the mechanism of action of the compound, and the presence of genetic mobile elements through horizontal gene transfer by conjugation assays. 
Humans once infected by a bacterium resistant to antibiotics that are commonly used to treat infections or resistant to disinfectants routinely used in animal production systems or hospitals, may have impaired treatment, higher costs and often need hospitalizations for longer periods (SHIRAKI et al., 2004; SAN MARTIN et al., 2005; JOHNSON et al., 2007; RIBEIRO et al., 2011). Our results indicate a problem of resistance to antimicrobials and disinfectants with severe consequences to public health, since most of the isolates were from meat products, showing the possibility of transmission of these bacteria to humans by the consumption of contaminated poultry-derived products.

\section{Conclusions}

Only very high doses of ceftiofur would be effective to treat salmonellosis caused by $\mathrm{SH}$, which would be too costly. Since ceftriaxone is also a third geration cephalosporin used to treat children with this disease, resistance to ceftiofur found in this study raises a major public health concern. Other studies have reported that $\mathrm{SH}$ is more invasive and persistant in the environment compared to other serotypes, and our study shows that $\mathrm{SH}$ can also be resistant to well-know disifectants used in the poultry industry. More studies should be conducted to investigate the mechanisms involved on $\mathrm{SH}$ resistance, besides the pump efflux system.

\section{Acknowledgements}

We thank FAPESC (Fundação de Apoio a Pesquisa do Estado de Santa Catarina, Edital PAP-UDESC) and National Council for Scientific and Technological Development (CNPq) for funding this work, and Mercolab Laboratories for providing the $\mathrm{SH}$ isolates.

\section{References}

BARROW, P. A.; JONES, M. A.; THOMSON, N. Pathogenesis of bacterial infection in animals. In: GYLES, C. L.; PRESCOTT, J. F.; SONGER, G.; THOEN, C. O. (Ed.). Salmonella. 4. ed. Iowa: Blackwell Publishing, 2010. p. 143-160.

BERCHIERI, A. J.; OLIVEIRA, G. H. Salmoneloses aviárias. In: ANDREATTI, R. L. (Ed.). Saúde aviária e doenças. São Paulo: Roca, 2006. p. 84-111.

BJORLAND, J.; STEINUM, T.; KVITLE, B.; WAAGE, S.; SUNDE, M.; HEIR, E. Widespread of disinfectant resistance genes among Staphylococcus of bovine and caprine origin in Norway. Journal of Clinical Microbiology, Washington, v. 43, n. 9, p. 4363-4368, 2005.

BRASIL. Ministério da Agricultura, Pecuária e Abastecimento. Métodos de análise microbiológica para alimentos. Diário Oficial [da] República Federativa do Brasil, Brasília, 17 ago. 1993, Seção I. p. 11937-11945.

BRAZILIAN ANIMAL PROTEIN ASSOCIATION ABPA. Poultry and swine breeding in Brazil: Production and Export; Predictions for 2015. 2015 Available at: $<$ http://abpa-br.com.br/noticia/avicultura-e-suinoculturado-brasil-producao-e-exportacao-previsoes-para2015-e-2016-1478>. Accessed at: 11 sept. 2017.

BUNCIC, S.; SOFOS, J. Interventions to control Salmonella contamination during poultry, cattle and pig slaughter. Food Research International. Ontario, v. 45, n. 2, p. 641-655, 2012.

CLINICAL AND LABORATORY STANDARDS INSTITUTE - CLSI. Norma M31-A3. Performance standards for antimicrobial disk and dilution susceptibility tests for bacteria isolated from animals. $3^{\text {rd }}$ ed. NCCLS, EUA. 2008. p. 13-25.

DUTIL, L. Ceftiofur resistance in Salmonella enterica serovar heidelberg from chicken meat and humans, Canada. Emerging Infectious Diseases, Atlanta, v. 16, n. 1, p. 48-54, 2010.

FIGUEIROA, A.; HAUCK, R.; SALDIASRODRIGUES, J.; GALLARDO, R. A. Combination of quaternary ammonia and glutaraldehyde as a disinfectant against enveloped and non-enveloped viruses. The Journal of Applied Poultry Research, Champaign, v. 26, n.4, p. 491-497, 2017.

FOLEY, S. L.; LYNNE, A. M. Food animal-associated Salmonella challenges: pathogenicity and antimicrobial resistance. Journal of Animal Science, Champaign, v. 86, n. 14, p. 173-187, 2007. Supplement. 
FRYE, J. G.; CRAY, P. J. Prevalence, distribution and characterization of ceftiofur resistance in Salmonella enterica isolated from animals in the USA from 1999 to 2003. International Journal of Antimicrobial Agents, v. 30, n. 2, p. 134-142, 2007.

GILBERT, P.; MCBAIN, A. J. Potential impact of increased use of biocides in consumer products on prevalence of antibiotic resistance. Clinical Microbiology, Bethesda, v. 16, n. 2, p. 189-208, 2003.

GREZZI, G. Limpeza e desinfecção na avicultura. In: CONFERÊNCIA APINCO DE CIÊNCIA E TECNOLOGIA, 2007, Campinas. Anais... Campinas: FACTA, 2007. p. 161-182.

ISENBERG, H. D. Essential procedures for clinical microbiology. American Society of Microbiology. Washington, DC: ASM Press, 1998. p. 890-924.

JOHNSON, J. R.; SANNES, M. R.; CROY, C.; JOHNSTON, B.; CLABOTS, C.; KUSKOWSKI, M. A.; BENDER, J.; SMITH, K. E; WINOKUR, P. L.; BELONGIA, E. A. Antimicrobial drug-resistant Escherichia coli from humans and poultry products, Minnesota and Wisconsin, 2002-2004. Emerging Infectious Diseases, Bethesda, v. 13, n. 6, p. 838-846, 2007.

KICH, J. D.; BOROWSKY, L. M.; SILVA, V. S.; RAMENZONI, M.; TRIQUES, N.; KOOLER, F. L.; CARDOSO, M. R. I. Avaliação da atividade antibacteriana de seis desinfetantes comerciais frente a amostras de Salmonella Typhimurium isoladas de suínos. Acta Scientiae Veterinariae, Porto Alegre, v. 32, n. 1, p. 33-39, 2004.

MEDEIROS, M. A. N.; OLIVEIRA, D. C. N.; RODRIGUES, D. P.; FREITAS, D. R. C. Prevalence and antimicrobial resistance of Salmonella in chicken carcasses at retail in 15 Brazilian cities. Revista Panamericana de Salud Publica. Washington, v. 30, n. 6, p. 555-560, 2011.

NEVES, G. B.; STEFANI, L. M.; PICK, E.; ARAUJO, D. N.; GIURIATTI, J.; PERCIO, C.; BRISOLA, M. C. Salmonella heidelberg isolated from poultry shows a novel resistance profile. Acta Scientiae Veterinariae. v. 44, p. 1-6, 2016.

PAIXÃO L.; RODRIGUES, L.; COUTO, I.; MARTINS, M.; FERNANDES, P.; CARVALHO, C. C. R.; MONTEIRO, G. A.; SANSONETTY, F.; AMARAL, L.; VIVEIROS, M. Fluorometric determination of ethidium bromide eflux kinetics in Escherichia coli. Journal Biomedical Engineering, Oxford, v. 3, n. 18, p. 1-13, 2009.

QUINN, P. J.; MARKEY, B. K.; CARTER, M. E.;
DONNELLY, W. J.; LEONARD, F. C. Microbiologia Veterinária e Doenças Infecciosas. In: QUINN, P. J. Porto Alegre: Artmed, 2005. p. 512-517.

RIBEIRO, V. B.; LINCOPAN, N.; LANDGRAF, N.; FRANCO, B. D. G. M.; DESTRO, M. T. Characterization of class 1 integrons and antibiotic resistance genes in multidrug resistant Salmonella enterica isolates from foodstuff and related sources. Brazilian Journal of Microbiology. São Paulo, v. 42, n. 2, p. 685-692, 2011.

RUSSEL, A. D. Antibiotic and biocide resistance in bacteria: introduction. Journal of Applied Microbiology, v. 92, p. 1S-3S, 2012. Supplement.

SAN MARTIN, B.; LAPIERRE, L.; TORO, C.; BRAVO, V.; CORNEJO, J.; HORMAZABAL. J. C.; BORIE, C. Isolation and molecular characterization of quinolone resistant Salmonella spp from poultry farms. Veterinary Microbiology, Victoria, v. 110, n. 3-4, p. 239-244, 2005.

SHIRAKI, Y.; SHIBATA, N.; DOI,Y.; ARAKAWA, Y. Escherichia coli producing CTX-M-2 beta-lactamase in cattle, Japan. Emerging Infectious Diseases, Atlantade, v. 10, n. 1, p. 69-75, 2004.

SUNDHEIM, G.; HAGTVEDT, T.; DAINTY, R. Resistance of meat associated staphylococci to a quaternary ammonium compound. Food Microbiology, Summit-Argo, v. 9, n. 2, p. 161-167, 1992.

TERZOLO, H. R. Estudio bacteriológico de las salmonelosis de las aves (S. Pullorum, S. Gallinarum, $S$. Enteritidis y S. Typhimurium) en América Latina. Balcarce: Instituto Nacional de Tecnologia Agropecuária, INTA, 2010. p. 1-19.

TRABULSI, L. R.; ALTERTHUM, F. Microbiologia. 5. ed. São Paulo: Atheneu, 2008. p. 760.

WALIA, K.; ARGÜELLO, H.; LYNCH, H.; GRANT, J.; LEONARD, F. C.; LAWLOR, P. G.; GARDINER, G. E.; DUFFY, G. The efficacy of different cleaning and disinfection procedures to reduce Salmonella and Enterobacteriaceae in the lairage environment of a pig abattoir. International Journal of Food Microbiology, v. 246, p. 64-71, 2017.

WEBSTER, C. R. L. Antibióticos: inibem a síntese da parede celular, interferem no metabolismo do dna e inibem a síntese protéica. In: . Farmacologia clínica em medicina veterinária. São Paulo: Roca, 2005. p. $75-81$.

ZHAO, S. Antimicrobial resistance in Salmonella enterica serovar heidelberg isolates from retail meats, Including Poultry from 2002 to 2006. Applied and Environmental Microbiology, Washington, v. 74, n. 21, p. 6656-6662, 2008. 
